\title{
Tumor necrosis factor- $\alpha$ enhances hyperbaric oxygen-induced visfatin expression via JNK pathway in human coronary arterial endothelial cells
}

\author{
Bao-Wei Wang ${ }^{1,2}$, Chiu-Mei Lin ${ }^{3}$, Gong-Jhe Wu ${ }^{4,5}$ and Kou-Gi Shyu ${ }^{2,5^{*}}$
}

\begin{abstract}
Background: Visfatin, a adipocytokine with insulin-mimetic effect, plays a role in endothelial angiogenesis. Hyperbaric oxygen (HBO) has been used in medical practice. However, the molecular mechanism of beneficial effects of HBO is poorly understood. We sought to investigate the cellular and molecular mechanisms of regulation of visfatin by HBO in human coronary arterial endothelial cells (CAECS).

Methods: Human CAECs were exposed to 2.5 atmosphere absolute (ATA) of oxygen in a hyperbaric chamber. Western blot, real-time polymerase chain reaction, and promoter activity assay were performed. In vitro glucose uptake and tube formation was detected.

Results: Visfatin protein (2.55-fold) and mRNA (2.53-fold) expression were significantly increased after exposure to 2.5 ATA HBO for 4 to $6 \mathrm{~h}$. Addition of SP600125 and JNK siRNA 30 min before HBO inhibited the induction of visfatin protein. $\mathrm{HBO}$ also significantly increased DNA-protein binding activity of AP-1 and visfatin promoter activity. Addition of SP600125 and TNF- $\alpha$ monoclonal antibody 30 min before HBO abolished the DNA-protein binding activity and visfatin promoter activity induced by $\mathrm{HBO}$. HBO significantly increased secretion of TNF- $\alpha$ from cultured human CAECs. Exogenous addition of TNF- $\alpha$ significantly increased visfatin protein expression while TNF- $\alpha$ antibody and TNF- $\alpha$ receptor antibody blocked the induction of visfatin protein expression induced by $\mathrm{HBO}$. HBO increased glucose uptake in human CAECs as HBO and visfatin siRNA and TNF- $\alpha$ antibody attenuated the glucose uptake induced by $\mathrm{HBO}$. HBO significantly increased the tube formation of human CAECs while visfatin siRNA, TNF$\alpha$ antibody inhibited the tube formation induced by $\mathrm{HBO}$.
\end{abstract}

Conclusions: HBO activates visfatin expression in cultured human CAECs. HBO-induced visfatin is mediated by TNF- $\alpha$ and at least in part through JNK pathway.

\section{Background}

Visceral fat accumulation has been shown to play crucial roles in the development of cardiovascular disease as well as the development of obesity-related disorders [1]. Recent evidences show that fat tissue is an active endocrine organ producing "adipocytokines", hormones that influence a diverse array of processes including appetite and energy balance, immunity, insulin sensitivity,

\footnotetext{
* Correspondence: shyukg@ms12.hinet.net

${ }^{2}$ Division of Cardiology, Shin Kong Wu Ho-Su Memorial Hospital, Taipei, Taiwan

Full list of author information is available at the end of the article
}

haemostasis, blood pressure, lipid metabolism and angiogenesis, all factors which can impact cardiovascular disease [2]. The recently discovered adipocytokine, visfatin, also known as pre-B cell colony-enhancing factor, has been demonstrated to mimic the glucose-lowering effect of insulin and improve insulin sensitivity [3]. However, the effects of visfatin are not restricted to glucose homeostasis. Visfatin was upregulated by hypoxia in adipocytes and in breast cancer cell through hypoxiainducible factor-1 $[4,5]$. Recently, visfatin was shown to play a role in endothelial angiogenesis by activation of fibroblast growth factor2, signal transducer and activator

\section{Ciomed Central}

(c) 2011 Wang et al; licensee BioMed Central Ltd. This is an Open Access article distributed under the terms of the Creative Commons Attribution License (http://creativecommons.org/licenses/by/2.0), which permits unrestricted use, distribution, and reproduction in any medium, provided the original work is properly cited. 
of transcription 3, and vascular endothelial growth factor and matrix metalloproteinase [6-9]. Several factors that could regulate visfatin synthesis have been identified $[10,11]$. Overall, visfatin is a cytokine with various functions [12].

Hyperbaric oxygen (HBO) therapy provides a significant increase in oxygen content in the hypoperfused tissue and the elevation in oxygen content in the hypoxic tissue induces powerful positive changes in ischemic repair process [13]. Therefore, HBO is successfully used for the treatment of a variety of clinical conditions [14]. HBO therapy promotes wound healing by directly enhancing fibroblastic replication, collagen synthesis, and the process of neovascularization in ischemic tissue [15].

Because of the emerging concept of coronary artery endothelial cells (CAECs) in the progress of angiogenesis and no data have been presented to verify the effect of $\mathrm{HBO}$ on the regulation of visfatin in human CAEC. Therefore we hypothesize that $\mathrm{HBO}$ activates a proinflammatory response mediated through a specific transcription factor, and downstream effects of this activation increased the expression of visfatin. Therefore, we sought to investigate the cellular and molecular mechanisms of regulation of visfatin by $\mathrm{HBO}$ in human CAECs. The induction of visfatin in human CAECs by HBO may elucidate the mechanisms responsible for the therapeutic effect of HBO.

\section{Methods}

\section{Primary human coronary artery endothelial cells (CAECs)} culture

Human coronary artery endothelial cells (CAECs) were originally obtained from PromoCell GmbH (Heidelberg, Germany). The cells were cultured in endothelial cell growth medium MV supplemented with $10 \%$ fetal bovine serum, $100 \mathrm{U} / \mathrm{ml}$ penicillin, and $100 \mu \mathrm{g} / \mathrm{ml}$ streptomycin at $37^{\circ} \mathrm{C}$ in a humidified atmosphere of $5 \% \mathrm{CO}_{2}$ in air. Cells were grown to $80-90 \%$ confluence in 10 $\mathrm{cm}^{2}$ culture dishes and were sub-cultured in the ratio of $1: 2$.

\section{HBO treatment}

For HBO treatment, cells were exposed to 2.5 ATA (atmosphere absolute) of oxygen (98\% oxygen plus $2 \%$ $\mathrm{CO}_{2}$ ) in a hyperbaric chamber for 2 to $8 \mathrm{~h}$ at $37^{\circ} \mathrm{C}$. The small hyperbaric chamber was put in a temperaturecontrolled $\left(37^{\circ} \mathrm{C}\right)$ incubator (Additional file 1, Figure $\mathrm{S} 1$ ). The oxygen tension was chosen based on the human treatment protocols [16]. For the inhibition of signal pathways, cells were pretreated with inhibitors for $30 \mathrm{~min}$, and then exposed to $\mathrm{HBO}$ without changing medium. SP600125 (20 $\mu$ M, CALBIOCHEM ${ }^{\circledR}$, San Diego, CA) is a potent, cell-permeable, selective, and reversible inhibitor of c-Jun $\mathrm{N}$-terminal kinase (JNK).
SB203580 (3 $\mu \mathrm{M}$, CALBIOCHEM $\left.{ }^{\circledR}\right)$ is a highly specific, cell permeable inhibitor of p38 kinase. PD98059 (50 $\mu \mathrm{M}$, CALBIOCHEM $^{\mathbb{R}}$ ) is a specific and potent inhibitor of extracellular-signal-regulated kinase (ERK) kinase. Wortmannin ((5 nM, Sigma Chemical, St. Louis, MO, USA) is a phosphatidylinositiol-3 (PI-3) kinase inhibitor.

\section{Western blot analysis}

Cells under $\mathrm{HBO}$ were harvested by scraping and then centrifuged $(300 \times \mathrm{g})$ for 10 minutes at $4^{\circ} \mathrm{C}$. The pellet was resuspended and homogenized in a Lysis Buffer (Promega Corp., Madison, WI, USA), centrifuging at $10,600 \times \mathrm{g}$ for 20 minutes. Bio-Rad Protein Assay was used for the measure of protein content. Equal amounts of protein $(15 \mu \mathrm{g})$ were loaded into a $12.5 \%$ SDS-polyacrylamide minigel, followed by electrophoresis. Proteins were electroblotted onto nitrocellulose. The blots were incubated overnight in Tris-buffered saline containing $5 \%$ milk to block nonspecific binding of the antibody. Proteins of interest were revealed with specific antibodies as indicated (1:1000 dilution) for 1 hour at room temperature followed by incubation with a 1:5000 dilution of horseradish peroxidase-conjugated polyclonal anti-rabbit antibody for $1 \mathrm{~h}$ at room temperature. The membrane was then detected with an enhanced chemiluminescence detection system (ECL, Amersham, Buckinghamshire, England). Equal protein loading of the samples was further verified by staining mouse antitubulin monoclonal antibody from Santa Cruz Biotechnology Inc. All Western blots were quantified using densitometry.

\section{RNA isolation and reverse transcription}

Total RNA was isolated from cells using the single-step acid guanidinium thiocyanate/phenol/chloroform extraction method. Total RNA (1 $\mu$ g) was incubated with 200 $\mathrm{U}$ of Moloney-Murine Leukemia Virus reverse transcriptase in a buffer containing a final concentration of 50 $\mathrm{mmol} / \mathrm{L}$ Tris-Cl (pH 8.3), $75 \mathrm{mmol} / \mathrm{L} \mathrm{KCl,} 3 \mathrm{mmol} /$ $\mathrm{MgCl}_{2}, 20 \mathrm{U}$ of RNase inhibitor, $1 \mu \mathrm{mol} / \mathrm{L}$ poly-dT oligomer, and $0.5 \mathrm{mmol} / \mathrm{L}$ of each $\mathrm{dNTP}$ in a final volume of $20 \mu \mathrm{L}$. The reaction mixture was incubated at $42^{\circ} \mathrm{C}$ for $1 \mathrm{~h}$ and then at $94^{\circ} \mathrm{C}$ for 5 minutes to inactivate the enzyme. A total of $80 \mu \mathrm{L}$ of diethyl pyrocarbonate treated water was added to the reaction mixture before storage at $-70^{\circ} \mathrm{C}$.

\section{Real-time quantitative PCR}

A Lightcycler (Roche Diagnostic s, Mannheim, Germany) was used for real -time PCR. cDNA was diluted 1 in 10 with nuclease-free water. $2 \mu \mathrm{L}$ of the solution was used for the Lightcycler SYBR -Green mastermix (Roche Diagnostics): $0.5 \mu \mathrm{mol} / \mathrm{L}$ primer, $5 \mathrm{mmol} / \mathrm{L}$ magnesium chloride, and $2 \mu \mathrm{L}$ Master SYBR-Green in 
nuclease-free water in a final volume of $20 \mu \mathrm{L}$. The initial denaturation phase for specific gene was $5 \mathrm{~min}$ at $95^{\circ} \mathrm{C}$ followed by an amplification phase as detailed below: denaturation at $95^{\circ} \mathrm{C}$ for $10 \mathrm{sec}$; annealing at $63^{\circ}$ $\mathrm{C}$ for $7 \mathrm{sec}$; elongation at $72^{\circ} \mathrm{C}$ for $8 \mathrm{sec}$; detection at $79^{\circ} \mathrm{C}$ and for 45 cycles. Amplification, fluorescence detection, and post - processing calculation were performed using the Lightcycler apparatus. Individual PCR products were analyzed for DNA sequence to confirm the purity of the product.

\section{Promoter activity assay}

Visfatin gene was amplified with forward primer, CCACCGACTCGTACAAG and reverse primer, GTG AGCCAGTAGCACTC. The amplified product was digested with MluI and BglII restriction enzymes and ligated into pGL3-basic luciferase plasmid vector (Promega) digested with the same enzymes. Site-specific mutations were confirmed by DNA sequencing. Plasmids were transfected into human CAECs using a low pressure-accelerated gene gun (Bioware Technologies, Taipei, Taiwan) essentially following the protocol from the manufacturer. Test plasmid at $2 \mu \mathrm{g}$ and control plasmid (pGL4-Renilla luciferase) $0.02 \mu \mathrm{g}$ was co-transfected with gene gun in each well, and then replaced by normal culture medium. Following 6 hours of HBO, cell extracts were prepared using Dual-Luciferase Reporter Assay System (Promega) and measured for dual luciferase activity by luminometer (Turner Designs).

\section{Electrophoretic mobility shift assay (EMSA)}

Nuclear protein concentrations from cells were determined by Bio-rad protein assay. Consensus and control oligonucleotides (Santa Cruz Biotechnology Inc.) were labeled by polynucleotides kinase incorporation of $\left[\gamma^{32} \mathrm{P}\right]$-ATP. After the oligonucleotide was radiolabeled, the nuclear extracts $(4 \mu \mathrm{g}$ of protein in $2 \mu \mathrm{l}$ of nuclear extract) were mixed with $20 \mathrm{pmol}$ of the appropriate $\left[\gamma^{32} \mathrm{P}\right]$-ATP -labeled consensus or mutant oligonucleotide in a total volume of $20 \mu \mathrm{l}$ for $30 \mathrm{~min}$ at room temperature. The samples were then resolved on a $4 \%$ polyacrylamide gel. Gels were dried and imaged by autoradiography. Controls were performed in each case with mutant oligonucleotides or cold oligonucleotides to compete with labeled sequences.

\section{Measurement of TNF- $\alpha$ concentration by enzyme-linked immunosorbent assay}

Conditioned medium from human CAECs subjected to $\mathrm{HBO}$ and those from control cells were collected for TNF$\alpha$ measurement. The level of TNF- $\alpha$ was measured by a quantitative sandwich enzyme immunoassay technique (Amersham Pharmacia Biotech, Buckinghamshire, England). The lowest limit of TNF- $\alpha$ ELISA kit was $5 \mathrm{pg} / \mathrm{ml}$.

\section{Capillary-like network formation Assay}

Capillary-like network formation was performed in an in vitro culture system. Matrigel $250 \mu \mathrm{L}$ (BD Biosciences, MA) was coated in a 24-well culture plate and allowed to solidify $\left(37^{\circ} \mathrm{C}, 1 \mathrm{hr}\right)$. Human CAECs were cultured on a Matrigel matrix and were exposed to 2.5 ATA of oxygen (98\% oxygen plus $2 \% \mathrm{CO}_{2}$ ) in a hyperbaric chamber for 6 hrs at $37^{\circ} \mathrm{C}$. After $\mathrm{HBO}$ treatment, cells were placed in a humidified incubator for $16 \mathrm{hrs}$ with an atmosphere of $5 \%$ $\mathrm{CO}_{2}$ at $37^{\circ} \mathrm{C}$. The capillary-like network formation was observed with a phase-contrast microscope (Nikon, Tokyo).

\section{Migration assay}

The migration activity of human CAECs was determined using the growth factor-reduced Matrigel invasion system (Becton Dickinson) following the protocol provided by the manufacturer. $5 \times 10^{4}$ cells were seeded on top of ECMatrix gel (Chemicon International, Inc., Temecula, CA). Cells were then incubated at $37^{\circ} \mathrm{C}$ for 6 $h$ with or without $\mathrm{HBO}$. Three different phase-contrast microscopic high-power fields per well were photographed. The migratory cells with positive stain were counted and the observer was blind to the experiment.

\section{Glucose uptake in cultured human CAECs}

Human CAECs were seeded on ViewPlate for $60 \mathrm{~min}$ (Packard Instrument Co., Meriden, CT) at a cell density of $5 \times 10^{3}$ cells/well in serum free medium for overnight. Recombinant human visfatin 100 ng/ml (AdipoGen, Inc., Incheon, Korea), visfatin siRNA, TNF- $\alpha$ antibody, or TNF- $\alpha$ was added to the medium. Glucose uptake was performed by adding $0.1 \mathrm{mmol} / \mathrm{l} 2$-deoxy-Dglucose and $3.33 \mathrm{nCi} / \mathrm{ml} 2-\left[1,2-{ }^{3} \mathrm{H}\right]$-deoxy-D-glucose for various periods of time. Cells were washed with phosphate-buffered saline twice. Non-specific uptake was performed in the presence of $10 \mu \mathrm{M}$ cytochalasin B and subtracted from all of the measured value. MicroScint$2050 \mu \mathrm{l}$ was added and the plate was read with TopCount (Packard Instrument Co., Meriden, CT). The radioactivity was counted and normalized to protein amount measured with a protein assay kit.

\section{Statistical analysis}

The data were expressed as mean \pm SD. Statistical significance was performed with analysis of variance (GraphPad Software Inc., San Diego, CA). Tukey-Kramer comparison test was used for pairwise comparisons between multiple groups after the ANOVA. A value of $\mathrm{P}<0.05$ was considered to denote statistical significance.

\section{Results}

$\mathrm{HBO}$ increases visfatin expression

To investigate the effect of $\mathrm{HBO}$ on the expression of visfatin protein, different degrees of ATA were used. As 
shown in Figure 1, the visfatin protein was significantly induced by $\mathrm{HBO}$ at 1.5, 2, and 2.5 ATA for $6 \mathrm{~h}$. Since 2.5 ATA provided most powerful induction of visfatin protein. The following experiments used 2.5 ATA as the hyperbaric stimulation. The oxygen saturation measured by Oxy-Check (HANNA Instruments, Inc., Woonsocket, WI) and $\mathrm{pO}_{2}$ measured by pHOx Plus $\mathrm{C}$ (Nova Biomedical, Waltham, MA) in the medium was $523 \%$ and $>800 \mathrm{mmHg}$, respectively after HBO treatment for $6 \mathrm{~h}$ and $77 \%$ and $175 \mathrm{mmHg}$, respectively in the control without $\mathrm{HBO}$ treatment. The levels of visfatin protein shown by Western blot analysis significantly increased at 4 and $6 \mathrm{~h}$ after $\mathrm{HBO}$ treatment (Figure 2A and 2B) as compared to control without treatment. Although visfatin protein level still maintained elevated after $8 \mathrm{~h}$ of $\mathrm{HBO}$ treatment, the level of visfatin protein tended to return to baseline level. Visfatin mRNA significantly increased at $2 \mathrm{~h}$ after $\mathrm{HBO}$ treatment, increased to maximal at $4 \mathrm{~h}$ and returned to baseline level at $8 \mathrm{~h}$ after $\mathrm{HBO}$ treatment (Figure 2C). Because visfatin protein was maximally induced at $6 \mathrm{~h}$ after $\mathrm{HBO}$ treatment, the following experiments were set for $\mathrm{HBO}$ treatment for 6 hours. To simulate the clinical application of HBO, $\mathrm{HBO}$ was also applied intermittently and repeatedly day by day at $1 \mathrm{~h}$ per day. The visfatin protein level increased by intermittent and repeat exposure was similar to that by $6 \mathrm{hr} \mathrm{HBO}$ exposure (Additional file 2, Figure S2)

HBO-induced visfatin protein expression in human CAECs is mediated by JNK kinase

As shown in Figure $3 \mathrm{~A}$ and $3 \mathrm{~B}$, the Western blot demonstrated that the HBO-induced increase of visfatin protein was significantly reduced after the addition of SB203580, and SP600125, 30 min before HBO treatment. The addition of PD98059 and wortmannin did not inhibit the visfatin protein expression induced by HBO. These findings implicated that JNK and ERK pathways but not p38 MAP kinase and PI-3 kinase mediated the induction of visfatin protein by $\mathrm{HBO}$ in

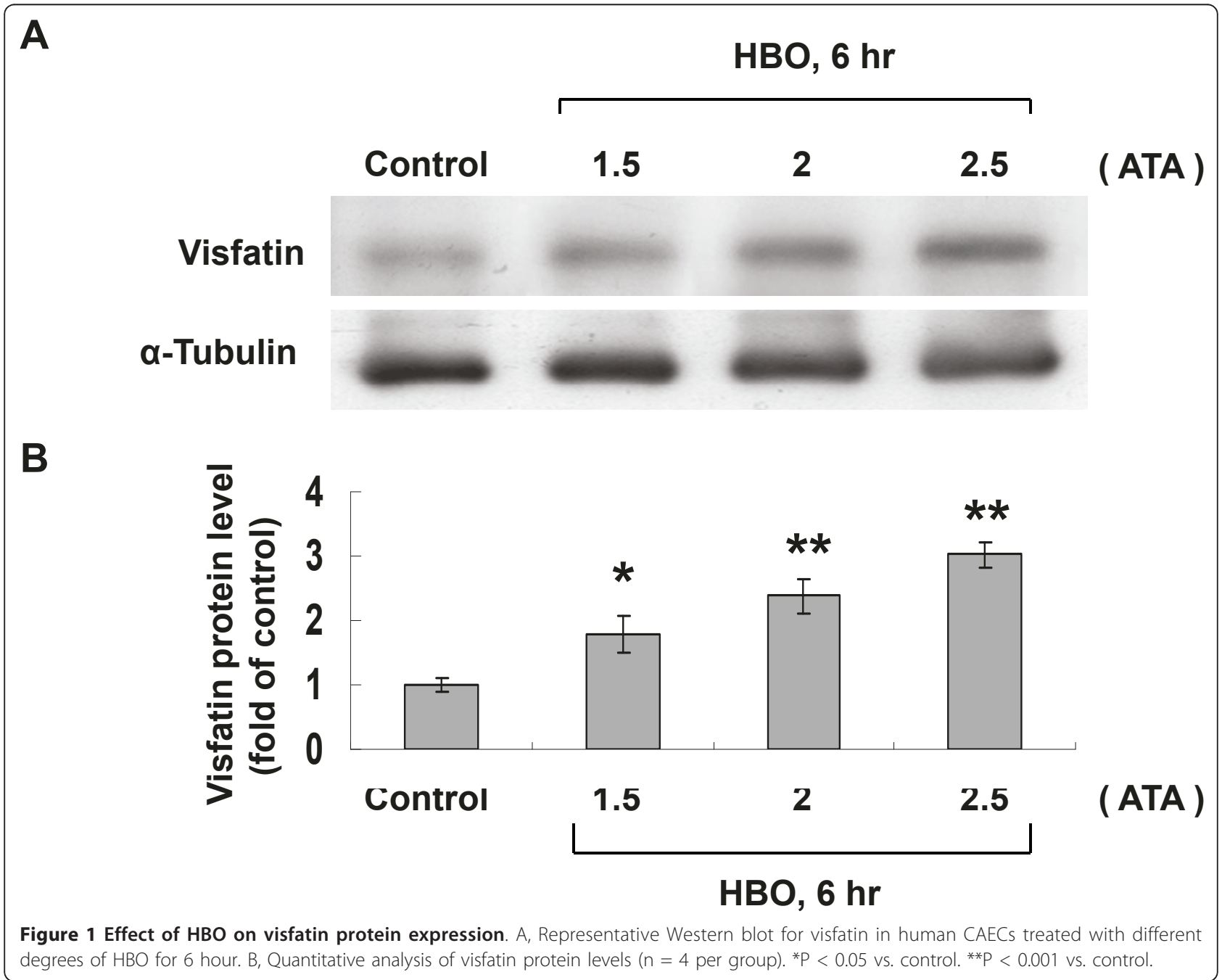




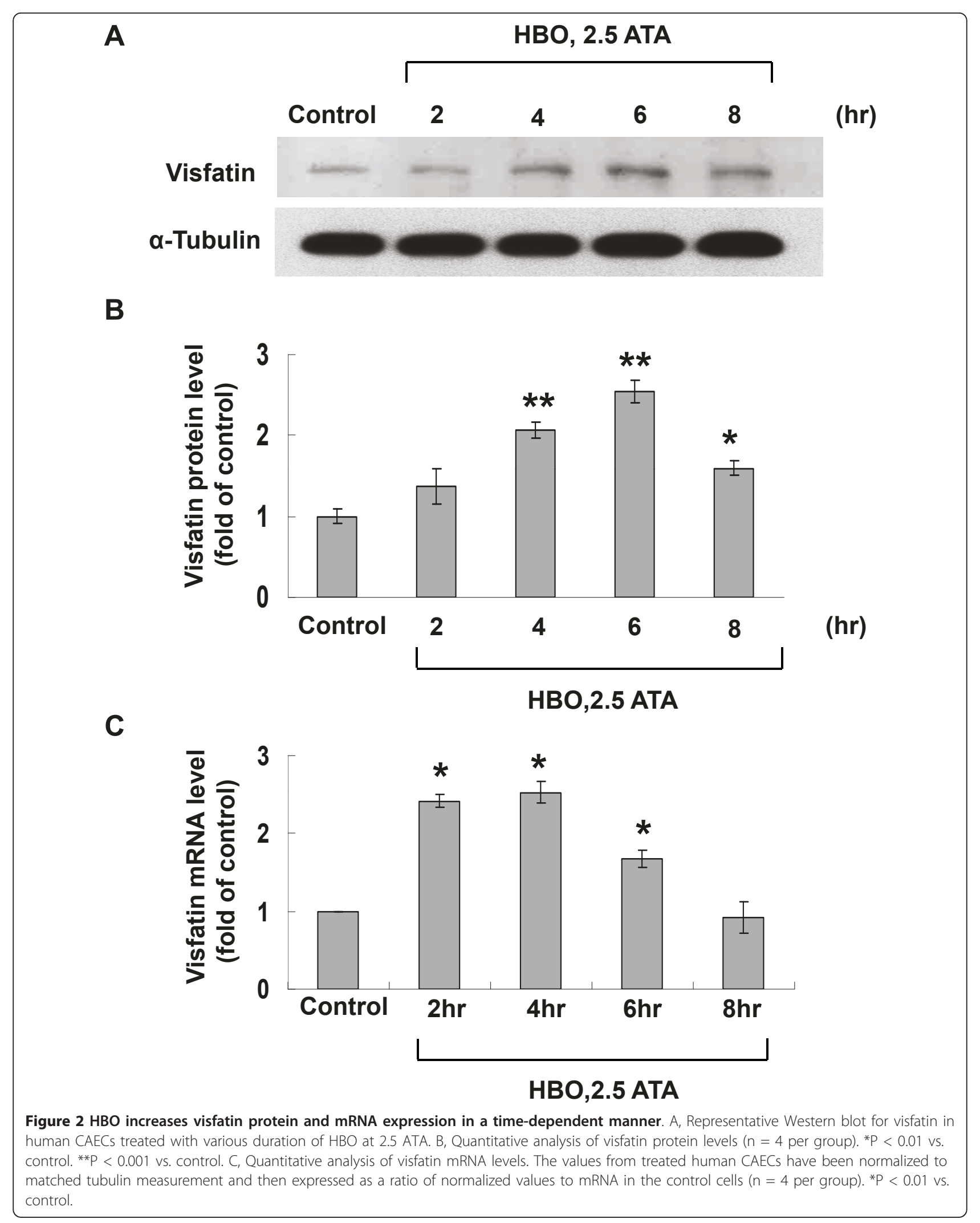


A

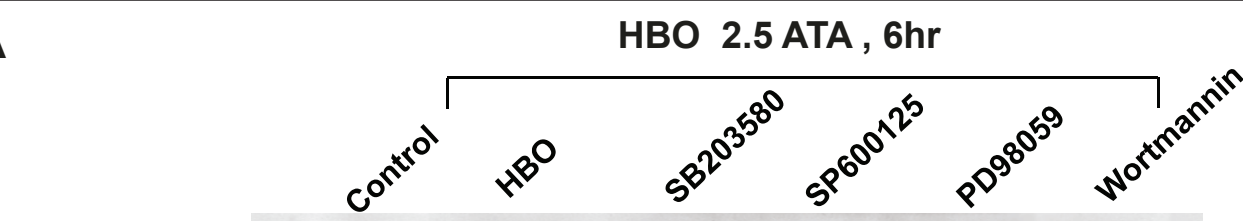

Visfatin a-Tubulin

B

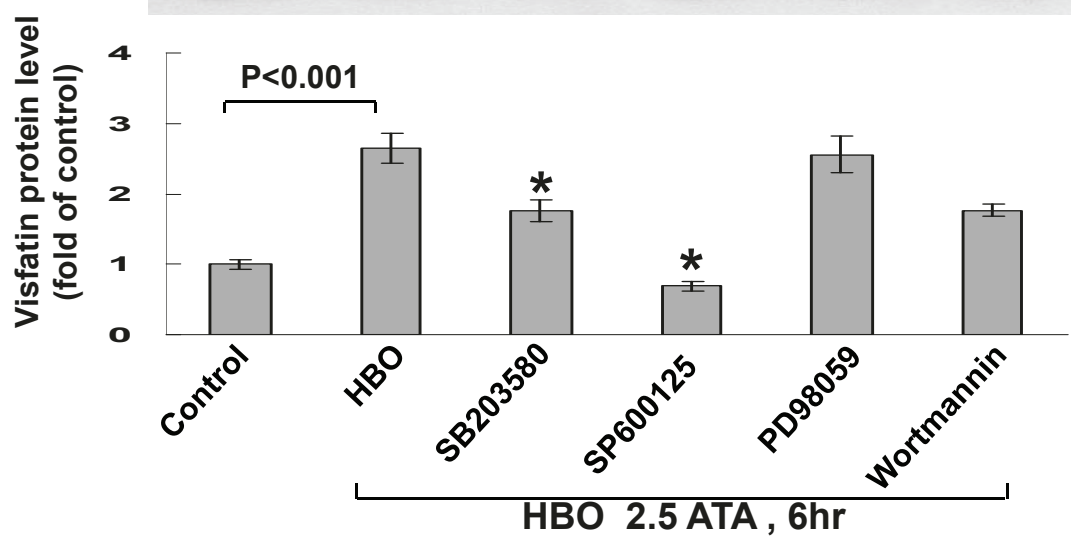

C

HBO, 2.5 ATA

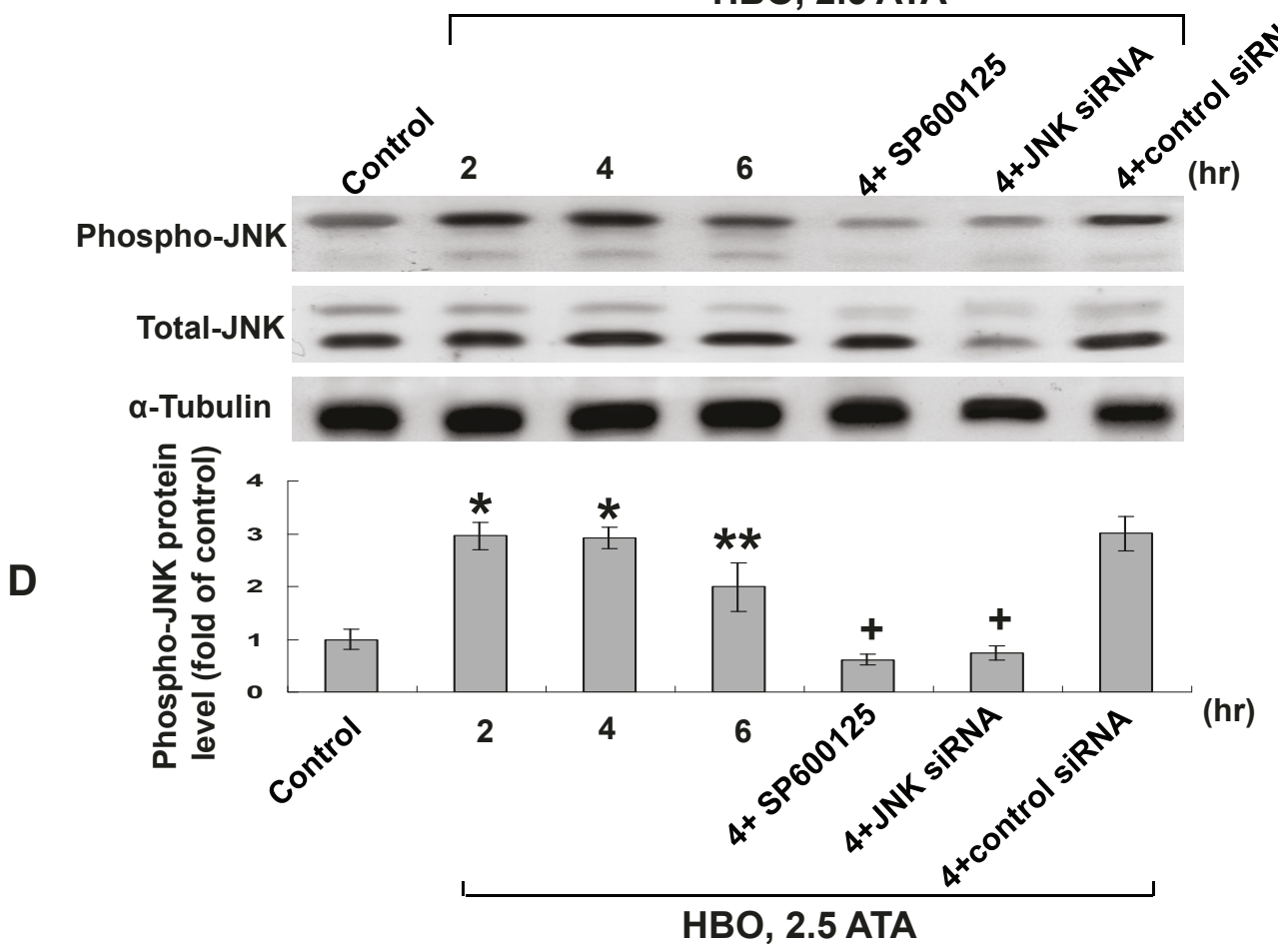

Figure 3 HBO-induced visfatin expression in human CAECs is via JNK kinase. A, Representative Western blots for visfatin protein levels in human CAECs subjected to HBO stimulation for $6 \mathrm{~h}$ in the absence or presence of inhibitors. B, Quantitative analysis of visfatin protein levels ( $\mathrm{n}$ $=4$ per group). ${ }^{*} P<0.001$ vs. HBO. C, Representative Western blots for phosphor-JNK and total JNK protein levels in human CAECs subjected to HBO stimulation for 2 to $6 \mathrm{~h}$ in the absence or presence of inhibitor or siRNA. D, Quantitative analysis of phosphor-JNK protein levels ( $n=4$ per group). ${ }^{*} P<0.001$ vs. control. ${ }^{* * P}<0.01$ vs. control. ${ }^{+} \mathrm{P}<0.001$ vs. $\mathrm{HBO}$ at $4 \mathrm{~h}$. 
human CAECs. Since JNK kinase inhibitor reduced the visfatin protein expression most significantly. We then focused on the JNK kinase pathway on the visfatin protein expression induced by $\mathrm{HBO}$. $\mathrm{HBO}$ at 2.5ATA significantly increased the phosphorylation of JNK (Figure 3C and 3D). SP600125, inhibitor of JNK kinase, significantly attenuated the increased phosphorylation of JNK induced by HBO. JNK siRNA significantly attenuated the expression of phosphor-JNK induced by HBO. The scrambled siRNA did not affect the phosphorylation of JNK induced by HBO.

\section{HBO-induced visfatin protein expression in human CAECs is mediated by TNF- $\alpha$}

Exogenous addition of TNF- $\alpha$ at $300 \mathrm{pg} / \mathrm{ml}$ significantly increased visfatin protein expression, similar to the level induced by $\mathrm{HBO}$ at 2.5 ATA (Figure 4). Exogenous addition of angiotensin II at $10 \mathrm{nM}$ also increased visfatin expression but the increased level was less than that induced by TNF- $\alpha$. Exogenous addition of IL- 6 at 10 $\mu \mathrm{g} / \mathrm{ml}$ did not increase visfatin expression. As shown in Figure 5A, $\mathrm{HBO}$ at 2.5 ATA significantly began to increase the TNF- $\alpha$ secretion from human CAECs at $2 \mathrm{~h}$ after $\mathrm{HBO}$ stimulation and remained elevated for $6 \mathrm{~h}$ and then returned to baseline level after $8 \mathrm{~h}$. The HBOinduced vifatin protein expression was significantly attenuated by the addition of TNF- $\alpha$ antibody $(5 \mu \mathrm{g} / \mathrm{mL})$ or TNF- $\alpha$ receptor antibody $(5 \mu \mathrm{g} / \mathrm{mL})$. Addition of control IgG did not abolish the induction of visfatin protein by HBO. Exogenous addition of TNF- $\alpha$ at $300 \mathrm{pg} / \mathrm{ml}$ also induced the visfatin protein expression (Figure $5 \mathrm{~B}$ and $5 \mathrm{C})$. These data indicate that TNF- $\alpha$ mediates the induction of visfatin protein expression by HBO. JNK siRNA but not control siRNA significantly inhibited the visfatin expression induced by TNF- $\alpha$

\section{HBO increases AP1-binding activity and visfatin promoter activity}

Treatment of $\mathrm{HBO}$ for $2 \mathrm{~h}$ to $6 \mathrm{~h}$ significantly increased the DNA-protein binding activity of AP-1 (Figure 6A). An excess of unlabeled AP-1 oligonucleotide competed with the probe for binding AP-1 protein, whereas an oligonucleotide containing a 2-bp substitution in the AP-1 binding site did not compete for binding. Addition of SP600125 and TNF- $\alpha$ monoclonal antibody $30 \mathrm{~min}$ before $\mathrm{HBO}$ stimulation abolished the DNA-protein binding activity induced by $\mathrm{HBO}$. Exogenous addition of TNF- $\alpha$ significantly increased the DNA-protein binding activity. To study whether the visfatin expression induced by $\mathrm{HBO}$ is regulated at the transcriptional level, we cloned the promoter region of human visfatin $(-889 \sim+16)$, and constructed a luciferase reporter plasmid (pGL3-Luc). The visfatin promoter construct contains AP-1, HIF- $1 \alpha$, and Stat- 4 binding sites. As shown in Figure $6 \mathrm{~B}$ and $6 \mathrm{C}$, transient transfection experiment in human CAECs using this reporter gene revealed that $\mathrm{HBO}$ for $6 \mathrm{~h}$ significantly induced visfatin promoter activation. This result indicates that visfatin expression is induced at transcriptional level by $\mathrm{HBO}$. When the AP-1 binding sites were mutated, the increased promoter activity induced by $\mathrm{HBO}$ was abolished. Moreover, addition of SP600125 and TNF- $\alpha$ antibody caused an inhibition of transcription. The increased promoter activity induced by exogenous addition of TNF- $\alpha$ was similar to that induced by $\mathrm{HBO}$ at $2.5 \mathrm{ATA}$. These results suggested that AP-1 binding site in the visfatin promoter is essential for the transcriptional regulation by $\mathrm{HBO}$ and that $\mathrm{HBO}$ regulates visfatin promoter via TNF- $\alpha$ and JNK pathways.

\section{Recombinant visfatin and $\mathrm{HBO}$ increase glucose uptake}

$\mathrm{HBO}$ and recombinant human visfatin at $100 \mathrm{ng} / \mathrm{ml}$ significantly increased glucose uptake at various periods of incubation as compared to control human CAECs without treatment (Figure 7). The glucose uptake in HBOtreated cells was similar to that in exogenous addition of visfatin and TNF- $\alpha$. Addition of visfatin siRNA or TNF- $\alpha$ antibody before HBO treatment attenuated the glucose uptake to baseline levels.

\section{HBO increases human CAECs tube formation and migration}

To test the effect of $\mathrm{HBO}$ on the function of human CAECs, tube formation and migration activity was examined. As shown in Figure 8, HBO for 6 h significantly increased the tube formation of human CAECs. Pretreatment with SP600125, TNF- $\alpha$ monoclonal antibody, and visfatin siRNA significantly blocked the induction of tube formation by $\mathrm{HBO}$. The control siRNA did not inhibit the tube formation induced by HBO. HBO for $6 \mathrm{~h}$ significantly increased the migration activity of human CAECs (Figure 9). Pretreatment with SP600125, TNF- $\alpha$ monoclonal antibody, and visfatin siRNA significantly blocked the induction of migration by HBO. The control siRNA did not inhibit the migration induced by HBO.

\section{Discussion}

In this study, we demonstrated several significant findings. Firstly, $\mathrm{HBO}$ induces transient visfatin expression in cultured human CAECs in a time- and load-dependent manner. Secondly, TNF- $\alpha$ acts as an autocrine factor to mediate $\mathrm{HBO}$-induced visfatin protein expression in human CAECs. Thirdly, JNK kinase and AP-1 transcription factor are involved in the signaling pathways of visfatin induction by $\mathrm{HBO}$. Fourthly, HBO increases tube formation and migration activity of human CAECs. The findings that $\mathrm{HBO}$ induces visfatin expression in human 
A

\section{$6 \mathrm{hr}$}

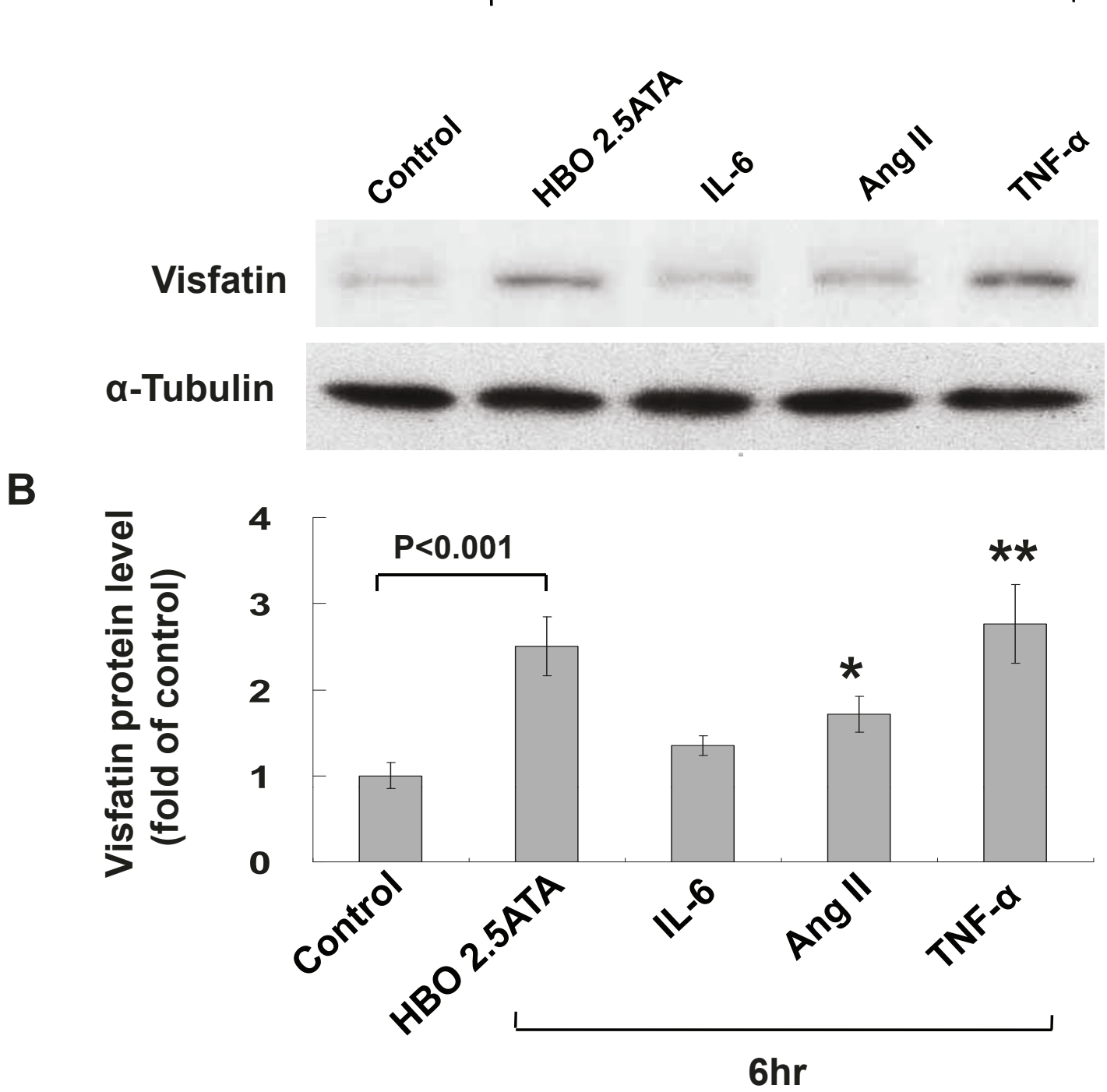

Figure 4 Tumor necrosis factor- $\alpha($ TNF- $\alpha$ ) increases visfatin expression. A, Representative Western blot for visfatin in human CAECs treated with different cytokines for 6 hour. B, Quantitative analysis of visfatin protein levels ( $n=4$ per group). ${ }^{*} P<0.05$ vs. control. ${ }^{* *} p<0.001$ vs. control.

CAECs and functionally human CAECs tube formation and migration increase by $\mathrm{HBO}$ may further strengthen the effect of $\mathrm{HBO}$ on angiogenesis. In addition to insulinmimetic effect, visfatin has been shown to induce angiogenesis via fibroblast growth factor, STAT-3 and vascular endothelial growth factor [6-8]. Recently, Adyaet al also reported that visfatin induces angiognesis via monocytechemoattractant protein-1 in human endothelial cells [17]. Our study confirmed the effect of angiogenesis of visfatin on human CAECs after $\mathrm{HBO}$ treatment.

Visfatin is a cytokine with various functions [12]. Recently, visfatin was shown to induce inflammatory cytokines expression in human endothelial cells and then caused endothelial dysfunction [18]. However, Lim et al. demonstrated cardio-protective effect of visfatin which is capable of reducing myocardial injury when administered at the time of myocardial reperfusion [19]. Our study demonstrated that HBO induced secretion of TNF- $\alpha$, an inflammatory cytokine, from human CAECs and TNF- $\alpha$ increased visfatin expression by autocrine mechanism because exogenous administration of TNF- $\alpha$ also enhanced visfatin expression and TNF- $\alpha$ and TNF- $\alpha$ receptor antibody attenuated the increase of visfatin by HBO. AP- 1 is a principal transcriptional factor that is activated by TNF- $\alpha$ and AP- 1 is a well-characterized downstream target of JNK. In this study, we demonstrated that 
A

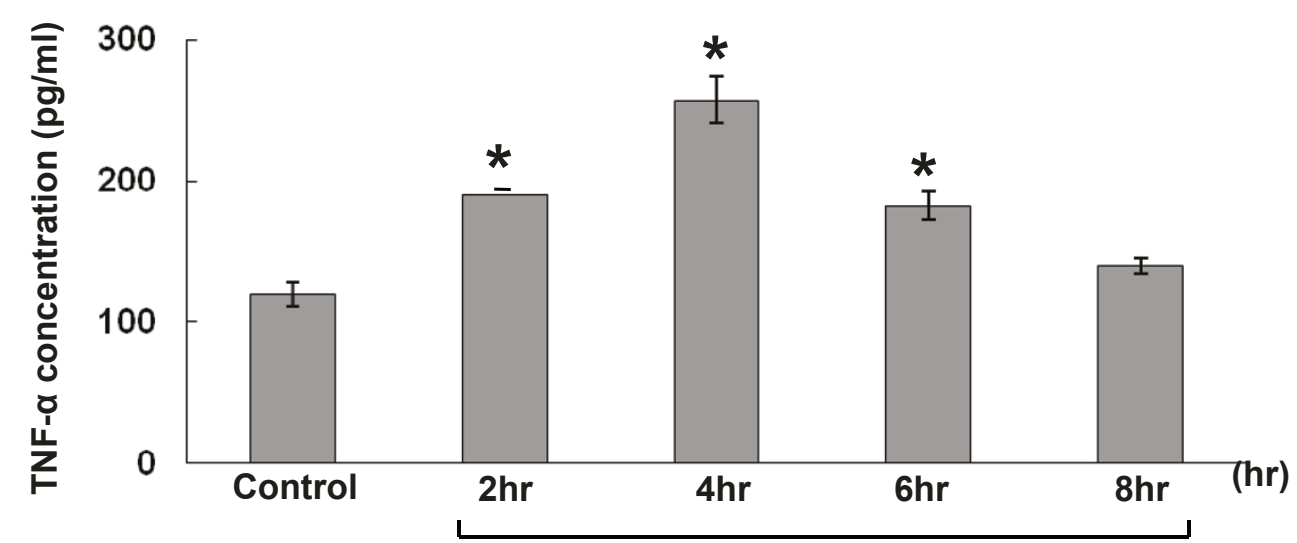

B

HBO, 2.5 ATA

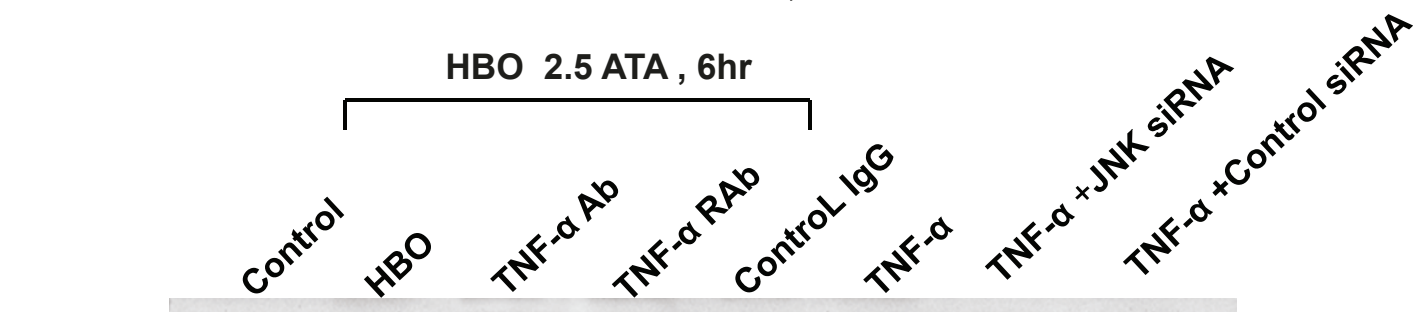

Visfatin

a-Tubulin

C

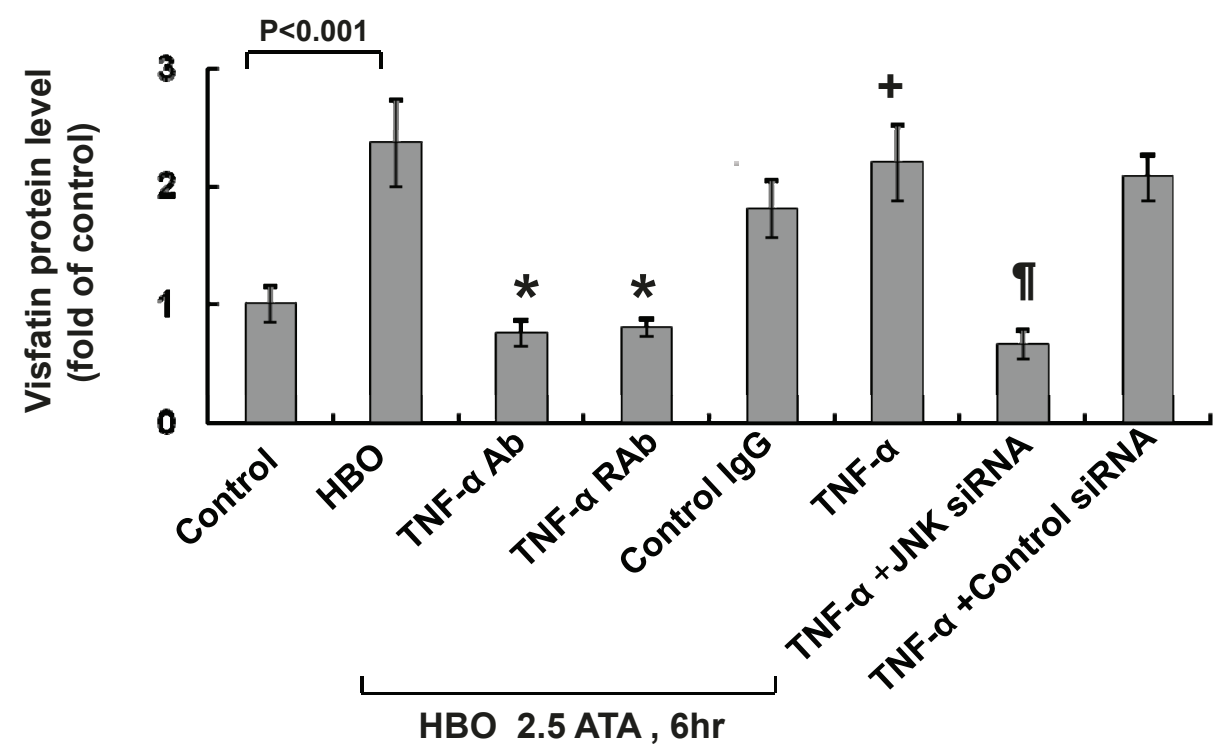

Figure 5 TNF- $\alpha$ mediates the induction of visfatin by HBO. A, HBO increased TNF- $\alpha$ secretion from human CAECS after HBO treatment. The secreted TNF- $\alpha$ was measured by ELISA method ( $n=4$ per group). ${ }^{*} P<0.01$ vs. control. B, Representative Western blots for visfatin protein levels in human CAECs subjected to HBO stimulation for $6 \mathrm{~h}$ in the absence or presence of TNF- $\alpha$, TNF- $\alpha$ monoclonal antibody, TNF- $\alpha$ receptor (TNF- $\alpha$ R) antibody and control lgG. (C) Quantitative analysis of visfatin protein levels ( $n=4$ per group). ${ }^{*} P<0.001$ vs. HBO. ${ }^{+} P<0.001$ vs. control. " $P<0.001$ vs. TNF- $\alpha$. 


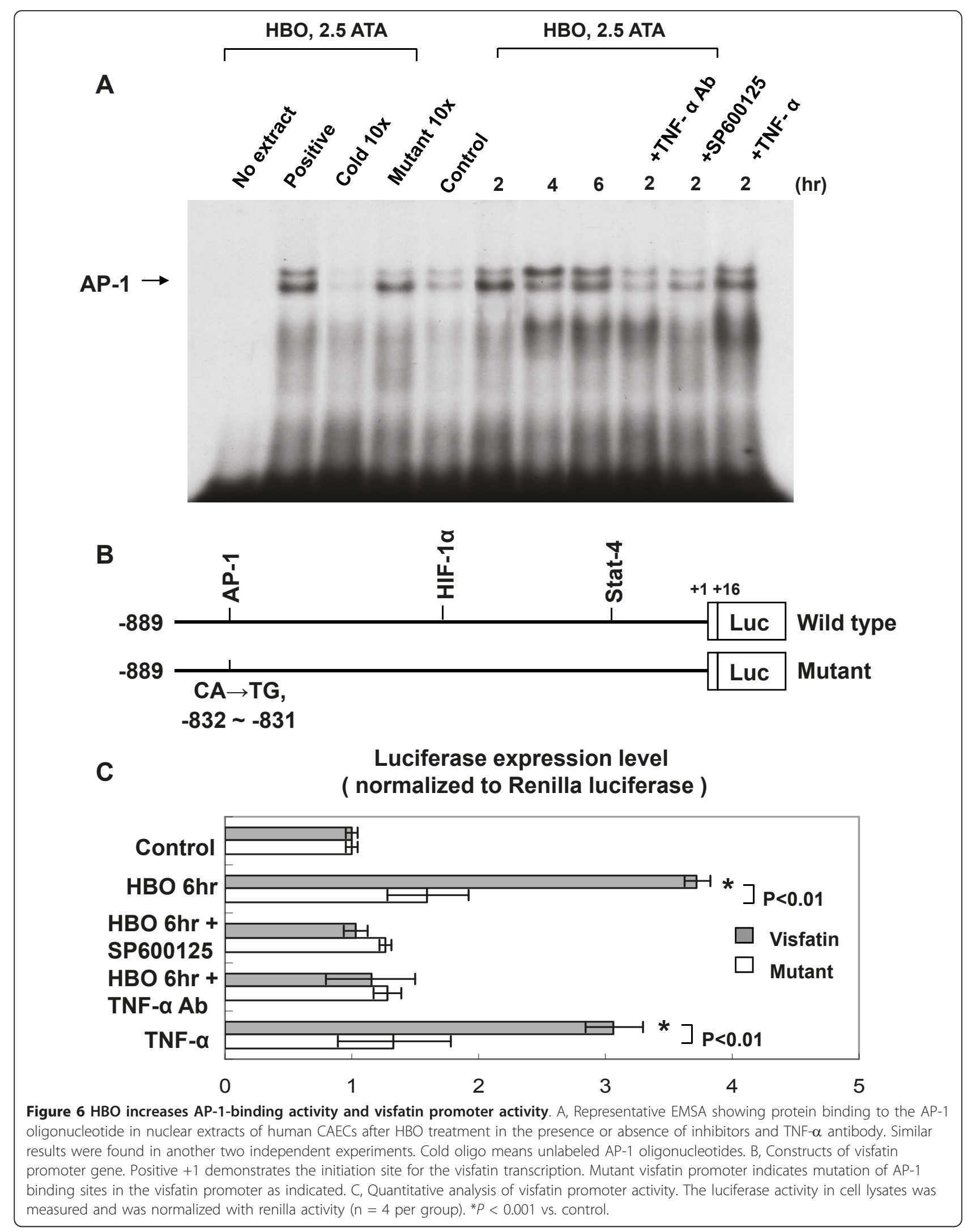




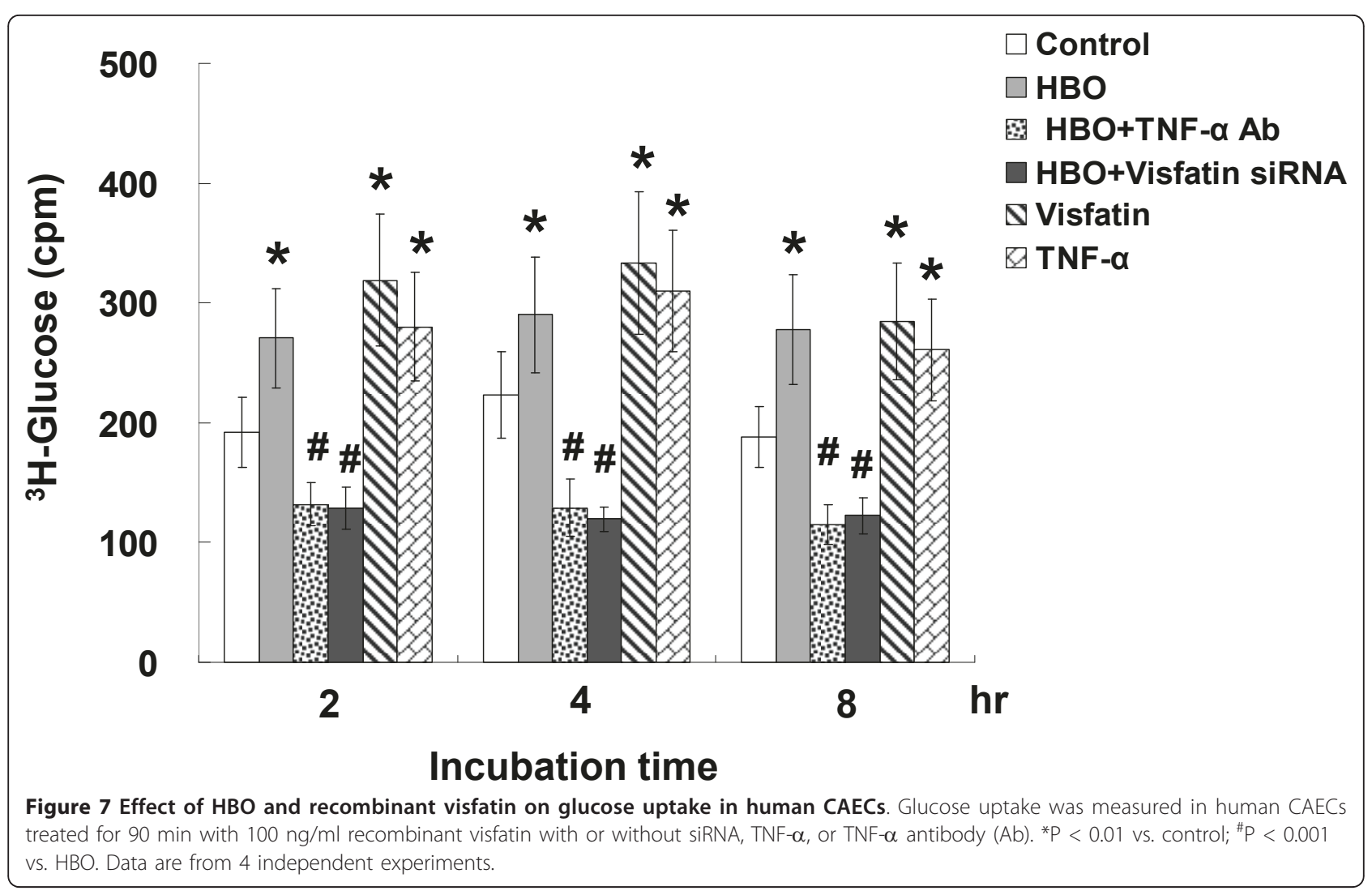

HBO increased AP-1 binding activity. TNF- $\alpha$ antibody and SP600125 inhibited the AP-1 binding activity induced by $\mathrm{HBO}$, indicating that TNF- $\alpha$ and JNK pathway mediate the increased transcriptional activity of AP-1 in the $\mathrm{HBO}$ model. Furthermore, TNF- $\alpha$ antibody and SP600125 attenuated the promoter activity of visfatin by $\mathrm{HBO}$. Our data also indicate that AP-1 binding site in the visfatin promoter is essential for the transcriptional regulation by $\mathrm{HBO}$ because a mutant AP-1 binding site in the visfatin promoter abolished the transcriptional activity induced by HBO.

We have used three proinflammatory cytokines to stimulate human CAECs. Interleukin- 6 did not have any effect on visfatin release and angiotensin II had partial effect on visfatin release. TNF- $\alpha$ produced most potent effect on visfatin release. Storka et al. have demonstrated no effect of angiotensin II on the release of visfatin from human umbilical vein endothelial cells, adipocytes and skeletal muscle cells [20]. The discrepancy result may indicate different cell types respond differently to proinflammatory cytokine stimulation to release visfatin.

Endothelial progenitor cell mobilization, homing and wound healing were enhanced by $\mathrm{HBO}$ through nitric oxide pathway [21-23]. However, the direct effect of $\mathrm{HBO}$ on human CAECs has not reported yet. In this study, we investigated the direct effect of $\mathrm{HBO}$ on human CAECs and demonstrated that $\mathrm{HBO}$ enhanced visfatin expression. HBO may induce different genes expression in different cell types via different signal pathways $[24,25]$. Hyperoxia with $100 \%$ oxygen has been shown to generate reactive oxygen species and produce vasoconstriction of coronary artery [26]. HBO is different with hyperoxia because hyperoxia is administered with normal baric pressure. The use of hyperbaric pressure of oxygen makes $\mathrm{HBO}$ a safe and noninvasive modality for the treatment of many kinds of diseases. In this study, $\mathrm{HBO}$ induces tube formation of human CAECs, an essential part for angiogenesis, indicating that $\mathrm{HBO}$ may be applied for patients with refractory ischemic heart diseases with non-optional therapy. In the study, $\mathrm{HBO}$ also significantly increased formation of reactive oxygen species for 2 to $8 \mathrm{~h}$ (Additional file 3, Figure S3). This result may suggest that $\mathrm{HBO}$ for 2-8 h causes oxygen toxicity.

In the present study, a protocol of 2.5 ATA $6 \mathrm{~h} \mathrm{HBO}$ is definitely not a "treatment" protocol. In the clinical treatment protocol, $\mathrm{HBO}$ is applied intermittently and repeatedly day by day at $1 \mathrm{~h}$ per day. Prolonged exposure to HBO causes significantly toxicity effects to the neurologic system as well as to any cultured cells. The visfatin induced by $\mathrm{HBO}$ in our study protocol may be caused by oxygen toxicity. In the present study, we found that HBO for $6 \mathrm{~h}$ increased human CAECs migration and proliferation, an early process of angiogenesis. 


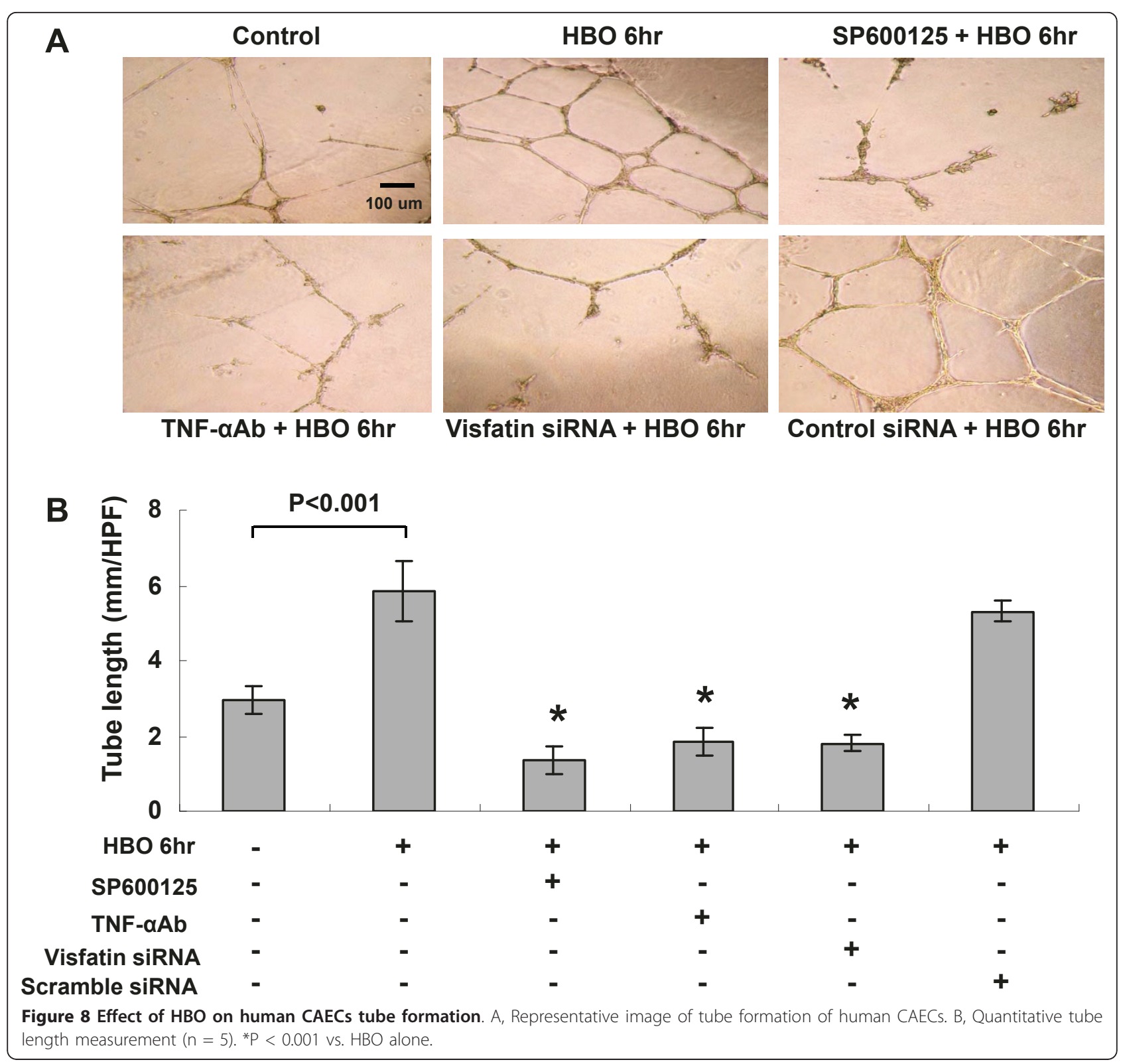

Exogenous addition of visfatin also increased migration of human CAECs without HBO stimulation (Additional file 4, Figure S4). Visfatin siRNA attenuated the migration and proliferation of human CAECs induced by HBO. MTT assay did not show significant cytotoxicity of $\mathrm{HBO}$ on human CAECs as compared to control or visfatin treatment (Additional file 4, Figure S4). The increased visfatin induced by $\mathrm{HBO}$ to increase angiogenesis may counteract the oxygen toxicity by prolonged HBO exposure.

Visfatin has been demonstrated to mimic the glucoselowering effect of insulin and improve insulin sensitivity [3]. In this study, we have demonstrated that $\mathrm{HBO}$ increases glucose uptake in human CAECs, similar to the effect of visfatin. Visfatin siRNA attenuated the glucose uptake by HBO. This finding indicates that visfatin mediates the glucose uptake by HBO in human CAECs. Glucose uptake increase by $\mathrm{HBO}$ may improve the energy metabolism in CAECs which may provide myocardial protection and anti-ischemic effect.

\section{Conclusions}

Our study reports for the first time that $\mathrm{HBO}$ enhances visfatin expression in cultured human CAECs. The $\mathrm{HBO}$-induced visfatin is mediated by TNF- $\alpha$ and at least in part through JNK pathway. Visfatin increases angiogenesis after $\mathrm{HBO}$, indicating that visfatin counteracts the oxygen toxicity by $\mathrm{HBO}$. 
A

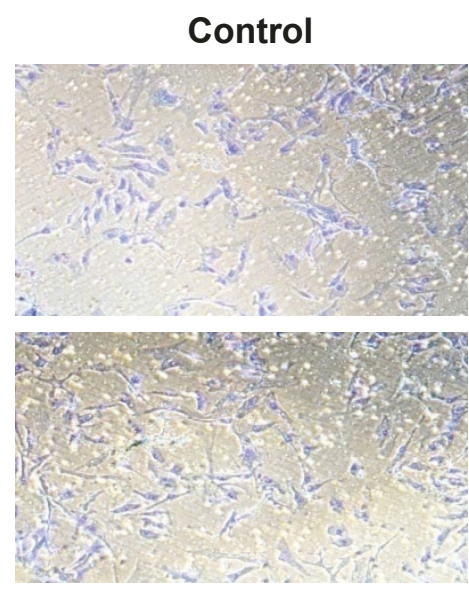

TNF- $\alpha A b+H B O 6 h r$

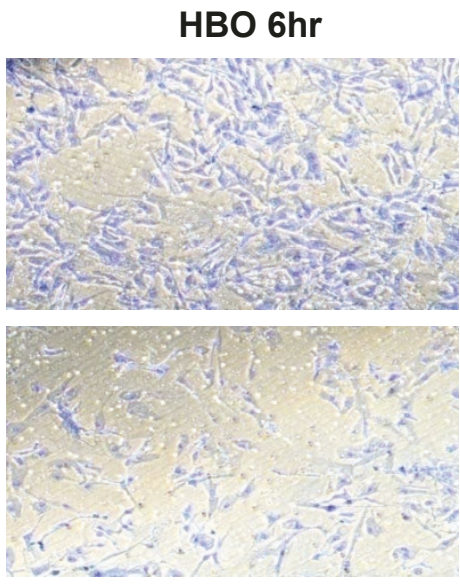

Visfatin siRNA + HBO 6hr

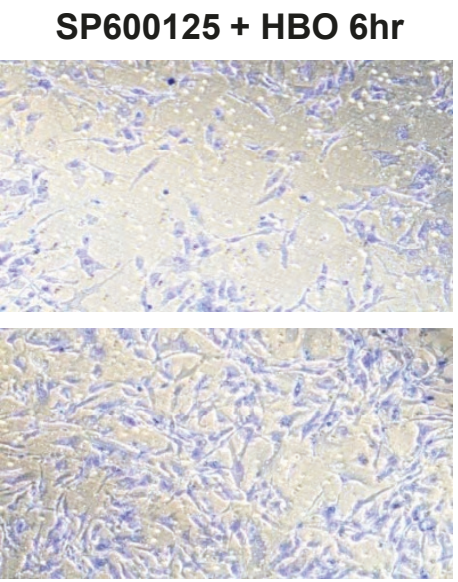

Control siRNA + HBO $6 \mathrm{hr}$

B
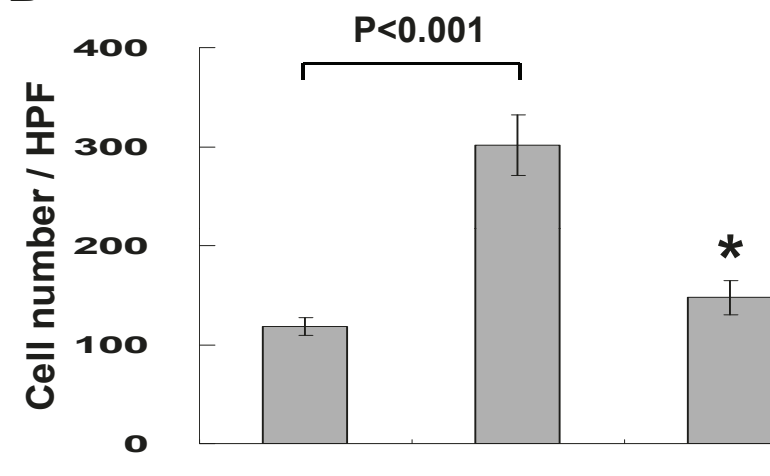

HBO $6 \mathrm{hr}$

SP600125

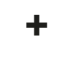

TNF- $\alpha A b$

Visfatin siRNA

Scramble siRNA

Figure 9 Effect of $\mathrm{HBO}$ on human CAECs migration. A, Representative image of migration of human CAECs. B, Quantitative migration activity measurement $(n=4)$. ${ }^{*} P<0.001$ vs. $\mathrm{HBO}$ alone.

\section{Additional material}

Additional file 1: Figure S1: Schematic diagram of hyperbaric chamber in incubator.

Additional file 2: Figure S2: Effect of intermittent and repeat $\mathrm{HBO}$ exposure on visfatin protein expression. $\mathrm{HBO}$ at 2.5 ATA was applied $1 \mathrm{~h}$ per day. A, Representative Western blot for visfatin in human CAECs treated with $\mathrm{HBO}$ at $1 \mathrm{~h}$ each day for different duration. B, Quantitative analysis of visfatin protein levels ( $n=4$ per group). ${ }^{*} P<0.05$ vs. control. **P $<0.001$ vs. control.

Additional file 3: Figure S3: Effect of $\mathrm{HBO}$ on reactive oxygen species (ROS) formation in human CAECs. A, Representative microscopic image for ROS assay with (left panel) or without green fluorescence (right panel). B, Quantitative analysis of the positive fluorescent cells. Control group indicates normoxia group. ( $n=4$ per group). ${ }^{*} \mathrm{P}<0.05$ vs. control. ${ }^{* *} \mathrm{P}<0.01$ vs. control.

Additional file 4: Figure S4: Effect of recombinant visfatin on migration and viability of human CAECs. A, Representative image of migration of human CAECs. B, Quantitative migration activity

measurement $(n=4)$. ${ }^{*} P<0.001$ vs. control. C, Quantitative analysis of viability by MTT assay.

\section{List of abbreviations used}

AP-1: activating protein-1; CAECs: coronary artery endothelial cells; ERK: extracellular-signal-regulated kinase; EMSA: electrophoretic mobility shift assay; HBO: hyperbaric oxygen; JNK: c-Jun N-terminal kinase; siRNA: small interfering RNA; TNF-a: tumor necrosis factor-a; TLR: toll-like receptor; TNF-a: tumor necrosis factor-a.

\section{Acknowledgements}

This study was sponsored in part from National Science Council, Executive Yuan, Taiwan.

\section{Author details}

${ }^{1}$ School of Medicine, Fu-Jen Catholic University, New Taipei City, Taiwan. ${ }^{2}$ Division of Cardiology, Shin Kong Wu Ho-Su Memorial Hospital, Taipei, 
Taiwan. ${ }^{3}$ Department of Emergency Medicien, Shin Kong Wu Ho-Su Memorial Hospital, Taipei, Taiwan. ${ }^{4}$ Department of Anesthesiology, Shin Kong Wu Ho-Su Memorial Hospital, Taipei, Taiwan. ${ }^{5}$ Graduate Institute of Clinical Medicine, Taipei Medical University, Taipei, Taiwan.

\section{Authors' contributions}

BWW has participated in the design of the study and has made substantial contributions to conception and design, or acquisition of data, or analysis and interpretation of data. CML has made substantial contributions to conception and design, or acquisition of data, or analysis and interpretation of data. GJW has made substantial contributions to conception and design, or acquisition of data, or analysis and interpretation of data. KGS has participated in the design of the study and drafted the manuscript. All authors have read and approved the final manuscript

\section{Competing interests}

The authors declare that they have no competing interests.

Received: 5 December 2010 Accepted: 4 May 2011

Published: 4 May 2011

\section{References}

1. Matsuzawa Y: The metabolic syndrome and adipocytokines. FEBS Lett 2006, 580:2917-2921

2. Matsuzawa Y: Therapy insight: adipocytokines in metabolic syndrome and related cardiovascular disease. Nat Clin Pract Cardiovasc Med 2006, 3:35-42.

3. Fukuhara A, Matsuda M, Nishizawa M, Segawa K, Tanaka M, Kishimoto K, Matsuki Y, Murakami M, Ichisaka T, Murakami H, Watanabe E, Takagi T, Akiyoshi M, Ohtsubo T, Kihara S, Yamashita S, Makishima M, Funahashi T, Yamanaka S, Hiramatsu R, Matsuzawa Y, Shimomura I: Visfatin: A protein secreted by visceral fat that mimics the effects of insulin. Science 2005, 307:426-430.

4. Segawa K, Fukuhara A, Hosogai N, Mortia K, Okuno Y, Tanaka M, Nakagawa Y, Kihara S, Funahashi T, Komuro R, Matsuda M, Shimomura I: Visfatin in adipocytes is upregulated by hypoxia through HIF-1adependent mechanism. Biochem Biophys Res Commun 2006, 349:873-882.

5. Bae SK, Kim SR, Kim JG, Kim JY, Koo TH, Jang HO, Yun I, Yoo MA, Bae MK: Hypoxic induction of human visfatin gene is directly mediated by hypoxia-inducible factor-1. FEBS Lett 2006, 580:4105-4113.

6. Bae YH, Bae MK, Kim SR, Lee JH, Wee HJ, Bae SK: Upregulation of fibroblast growth factor-2 by visfatin that promotes endothelia angiogenesis. Biochem Biophys Res Commun 2009, 379:206-211.

7. Kim JY, Bae YH, Bae MK, Kim SR, Park HJ, Wee HJ, Bae SK: Visfatin through STAT3 activation enhances IL-6 expression that promotes endothelial angiogenesis. Biochim Biophys Acta 2009, 1793:1759-1767.

8. Adya R, Tan BK, Punn A, Chen J, Randeva HS: Visfatin induces human endothelial VEGF and MMP-2/9 production via MAPK and PI3K/Akt signaling pathways: novel insights into visfatin-induced angiogenesis. Cardiovasc Res 2008, 78:356-365.

9. Kim SR, Bae SK, Choi KS, Park SY, Jun HO, Lee JY, Jang HO, Yun H, Yoon KH, Kim YJ, Yoo MA, Kim KW, Bae MK: Visfatin promotes angiogenesis by activation of extracellular signal-regulated kinase 1/2. Biochem Biophys Res Commun 2007, 357:150-156.

10. Kralisch S, Klein J, Lossner U Bluher M, Paschke R, Stumvoll M, Fasshauer M: Hormonal regulation of the novel adipocytokine visfatin in 3T3-L1 adipocytes. J Endocrinol 2005, 185:R1-R8.

11. Kralisch S, Klein J, Lossner U, Bluher M, Paschke R, Stumvoll M, Fasshauer M: Interleukin-6 is a negative regulator of visfatin gene expression in 3T3L1 adipocytes. Am J Physiol Endocrinol Metab 2005, 289:E586-90.

12. Pilz S, Mangge H, Obermayer-Pietsch B, Marz W: Visfatin/pre-B-cell colonyenhancing factor: A protein with various suggested functions. J Endocrinol Invest 2007, 30:138-144.

13. Gill AL, Bell CAN: Hyperbaric oxygen in uses, mechanisms of action and outcomes. Q J Med 2004, 97:385-395.

14. Mayer R, Hamilton-Farrell MR, van der Kleij AJ, Schmutz J, Granstrom G, Sicko Z, Melamed Y, Carl UM, Hartmann KA, Jansen EC, Ditri L, Sminia P: Hyperbaric oxygen and radiotherapy. Strahlenther Onkol 2005, 181:113-123.

15. LaVan FB, Hunt TK: Oxygen and wound healing. Clinics in Plastic Surg 1990, 17:463-472.
16. Bouachour G, Cronier P, Gouello JP, Toulemonde JL, Talha A, Alquier P: Hyperbaric oxygen therapy in the management of crush injuries: a randomized double-blind placebo-controlled clinical trial. J Trauma 1996, 41:333-339.

17. Adya R, Tan BK, Chen J, Randeva HS: Pre-B cell colony enhancing factor (PBEF)/visfatin induces secretion of MCP-1 in human endothelial cells: Role in visfatin-induced angiogenesis. Atherosclerosis 2009, 205:113-119.

18. Lee WJ, Wu CS, Lin H, Lee IT, Wu CM, Tseng JJ, Chou MM, Sheu WHH: Visfatin-induced expression of inflammatory mediators in human endothelial cells through the NF-KB pathway. Int J Obesity 2009, 33:465-472.

19. Lim SY, Davidon SM, Paramanathan AJ, Smith CCT, Yellon DM, Hausenloy DJ: The novel adipocytokine visfatin exerts direct cardioprotective effects. J Cell Mol Med 2008, 12:1395-1403.

20. Storka A, Vojtassakova E, Mueller M, Kapiotis S, Haider DG, Jungbauer A, Wolzt M: Angiotensin inhibition stimulates PPARy and the release of visfatin. Eur J Clin Invest 2008, 38:820-826.

21. Thom SR, Bhopale VM, Velazquez OC, Goldstein L, Thom LH, Buerk DG: Stem cell mobilization by hyperbaric oxygen. Am J Physiol Heart Circ Physiol 2006, 290:H1378-H1386.

22. Goldstein LJ, Gallagher KA, Bauer SM, Bauer RJ, Baireddy V, Liu ZJ, Buerk DG, Thom SR, Velazquez OC: Endothelial progenitor cell release into circulation is triggered by hyperoxia-induced increases in bone marrow nitric oxide. Stem Cells 2006, 24:2309-2318.

23. Gaallagher KA, Liu ZJ, Xiao M, Chen H, Goldstein LJ, Buerk DG, Nedeau A, Thom SR, Velazquez OC: Diabetic impairments in NO-mediated endothelial progenitor cell mobilization and homing are reversed by hypoxia and SDF-1a. J Clin Invest 2007, 117:1249-1259.

24. Shyu KG, Wang BW, Chang H: Hyperbaric oxygen activates discoidin domain receptor 2 via tumor necrosis factor-alpha and the p38 MAPK pathway to increase vascular smooth muscle cell migration through matrix metalloproteinase 2. Clin Sci 2009, 116:575-583.

25. Lee CC, Chen SC, Tsai SC, Wang BW, Liu YC, Lee HM, Shyu KG: Hyperbaric oxygen induces VEGF expression through ERK, JNK and c-Jun/AP-1 activation in human umbilical vein endothelial cells. J Biomed Sci 2006, 13:143-156.

26. Moradkhan R, Sinoway LI: Revisiting the role of oxygen therapy in cardiac patients. J Am Coll Cardiol 2010, 56:1013-1016.

doi:10.1186/1423-0127-18-27

Cite this article as: Wang et al: Tumor necrosis factor- $\alpha$ enhances hyperbaric oxygen-induced visfatin expression via JNK pathway in human coronary arterial endothelial cells. Journal of Biomedical Science 2011 18:27.

\section{Submit your next manuscript to BioMed Central and take full advantage of:}

- Convenient online submission

- Thorough peer review

- No space constraints or color figure charges

- Immediate publication on acceptance

- Inclusion in PubMed, CAS, Scopus and Google Scholar

- Research which is freely available for redistribution

Submit your manuscript at www.biomedcentral.com/submit
C BioMed Central 